\title{
EFISIENSI KINERJA LEMBAGA AMIL ZAKAT DALAM MENGELOLA DANA ZIS DENGAN METODE DEA (STUDI PADA YDSF SURABAYA)
}

\section{Rusmini, Tony Seno Aji}

\author{
Ekonomi Islam, Fakultas Ekonomi, Universitas Negeri Surabaya \\ E-mail: rusminirusmini@mhs.unesa.ac.id \\ Ekonomi Islam, Fakultas Ekonomi, Universitas Negeri Surabaya \\ E-mail: tonyseno@unesa.ac.id
}

\begin{abstract}
Efficiency is a parameter to measure the performance of companies and organizations. As an institution in charge of managing the funds of the people, this institution need for special attention, it use to see the professionalism of these institutions manage ZIS fund. This study aims to determine the efficiency of the management of zakat, donation and sadaqah (ZIS) at amil zakat Yayasan Dana Sosial Al - Falah (YDSF) Surabaya by using descriptive quantitative approach. The technique of collecting data in the form of documentation and interviews, using secondary data in the form of financial statements institute period 2015 - 2017. The data analysis technique uses data envelopment analysis (DEA) with the production approach, the orientation of the input and output. Input variables include total assets and operating costs, while the output variable : revenue and channeling of ZIS fund, using the assumption of a variable return to scale (VRS). The results showed that the production approach Yayasan Dana Sosial Al - Falah (YDSF) had maximum efficiency with a value of 100 percent or 1, in the period 2015, 2016 and 2017. Based on these results mean Yayasan Dana Sosial Al - Falah (YDSF) has reached optimal performance in managing ZIS, it proved by using input and output which is in accordance with the actual value and the target at the measurement Data envelopment analysis (DEA).
\end{abstract}

Keywords : $\quad$ Efficiency, ZIS, Data Envelopment Analysis.

\section{PENDAHULUAN}

Penghimpunan dana zakat, infak, dan sedekah setiap tahunnya mengalami peningkatan yang signifikan, total penghimpunan tahun 2017 saja mencapai 6,2 triliun rupiah (BAZNAS,2019 : 14). Namun peningkatan penerimaan dana zakat belum sebanding dengan potensi yang ada, masih terjadi adanya kesenjangan antara potensi dan realisasi penghimpunan. Besaran dana zakat yang diterima hanya kurang dari $1 \%$ dari total potensi yang ada sebesar 217 triliun rupiah, perlu adanya pengoptimalan dalam kinerja organisasi pengelola zakat (Canggih et al, 2017: 16).

Semakin besar potensi yang ada, maka semakin besar masalah yang dihadapi dalam oleh lembaga amil zakat penghimpunan maupun pengelolaan yang dihadapi lembaga amil zakat. Beberapa faktor masih rendahnya penghimpunan, maupun penyaluran yakni pada kepuasan, kepercayaan muzaki terhadap lembaga zakat. Selain itu masalah lain yang sering dihadapi lembaga zakat yakni terkait dengan transparansi dan profesionalisme lembaga dalam mengelola dana zakat, infak,dan 
sedekah, hasil penelitian menunjukkan bahwa $23 \%$ presepsi muzaki non-organisasi OPZ menilai bahwa organisasi pengelola zakat telah bekerja secara transparan, dan sebesar 15\% menilai OPZ telah bekerja secara profesional. Salah satu bentuk pertanggung jawaban lembaga zakat terhadap dana yang telah dikelola yaitu dalam bentuk transparansi lembaga. Serta perlu adanya pengelolaan secara profesional dan amanah, dengan adanya profesionalisme pengelolaan akan muncul kepercayaan masyarakat terhadap organisasi pengelola zakat (Mukhlis dan Beik, 2013: 101).

Berdasarkan penelitian terdahulu, mengenai efisiensi lembaga amil zakat peneliti menemukan beberapa fakta bahwasanya masih terdapat beberapa lembaga zakat yang didirikan oleh pemerintah maupun masyarakat mengalami inefisien (tidak efisien) dalam mengelola dana zakat, infak, dan sedekah. Penyebab inefisien karena masih adanya penggunaan berlebihan pada dana operasional lembaga, adanya ketidak proporsional antara penggunaan dana untuk operasional lembaga, dengan penerimaan maupun penyaluran dana zakat,infak, dan sedekah oleh lembaga.

Penelitian yang dilakukan oleh Mawaryani (2016 : 6), Sebagai lembaga yang bertugas sebagai penghimpun maupun menyalurkan dana ZIS, terdapat beberapa lembaga yang tergolong efisien yaitu Dompet Dhuafa dan PKPU, serta lembaga yang inefisien terjadi pada Rumah zakat. Penyebab inefisien ini terjadi karena penggunaan biaya operasional yang berlebihan namun belum mampu meningkatkan penghimpunan, serta perlu adanya penambahan pada penghimpunan guna menaikkan penyaluran dana zakat, infak, dan sedekah.

Kemudian, pada penelitian Wahyuny (2016:8), penelitian ini menunjukkan lembaga zakat sebagai lembaga penghimpun dan pendistribusi dana zakat menunjukkan efisiensi terjadi pada dua sampel penelitian yaitu Lazis NU dan PKPU. Sedangkan inefisiensi terjadi pada dua sampel penelitian, yaitu BAZNAS, Dompet Dhuafa. Penyebab inefisien terjadi pada penggunaan biaya operasional, biaya personalia, dan biaya sosialisasi. Kemudian meningkatkan penyaluran dana ZIS untuk mencapai kinerja yang efisien.

Organisasi pengelola zakat merupakan organisasi yang bersifat nirlaba, seluruh biaya operasional diambil dari dana zakat, infak dan sedekah yang terhimpun, dana yang tidak dikelola dengan baik akan mengalami penggunaan biaya berlebihan yang seharusnya dapat ditekan (Akbar,2009 : 761) Ketika lembaga amil zakat masih belum optimal dalam penggunaan biaya operasional lembaga, tentunya akan berakibat pada berkurangnya jumlah penyaluran dana zakat, infak, dan sedekah kepada penerima manfaat. Oleh karena itu, perlu adanya pengukuran kinerja lembaga zakat dalam upaya pengoptimalan pengelolaan dana zakat, infak, dan sedekah.

Melihat potensi ZIS yang besar dan berbagai problematika yang dihadapi maka perlu adanya pengelolaan zakat secara melembaga untuk meningkatkan daya guna dan hasil guna dana zakat, infak, dan sedekah sesuai dengan Undang - undang no. 23 tahun 2011 yaitu sesuai dengan syariat islam,kepastian hukum, kemanfaatan, keadilan, amanah, terintegritas dan akuntabilitas sehingga dapat meningkatkan efektivitas dan efisiensi pelayanan dalam pengelolaan zakat. Selain itu perlu adanya, 
standarisasi yang baik dimana salah satu indikatornya adalah efisiensi dan efektifitas sebagai tolak ukur kinerja lembaga (Wulandari, 2014 :5).

Efisiensi merupakan parameter untuk mengukur kinerja suatu perusahaan atau organisasi, melalui pengukuran pada aktivitas keuangan lembaga. Semakin efisien lembaga profit maupun nonprofit dalam mengelola dana maka akan semakin baik kinerjanya.Kemudian, ketika lembaga zakat bekerja semakin efisien dalam mengelola zakat, maka akan memberikan dampak positif dalam pelaksanaan pengumpulan, pengelolaan, pendistribusian. sehingga akan berdampak pada kepercayaan muzaki maupun masyarakat terhadap kredibilitas lembaga dalam mengelola dana zakat. Efisiensi sangat diperlukan bagi organisasi pengelola zakat untuk mewujudkan kemanfaatan yang lebih besar bagi umat.

Berdasarkan uraian diatas, penelitian ini berusaha menganalisis tingkat efisiensi lembaga amil zakat Yayasan Dana Sosial Al- Falah (YDSF) Surabaya dalam menghimpun maupun menyalurkan dana zakat, infak dan sedekah. Penelitian ini akan menguji pengaruh variabel output dan input pada lembaga amil zakat Yayasan Dana Sosial Al- Falah (YDSF) Surabaya periode 2015 - 2017, dengan metode Data Envelopment Analysis (DEA). Sehingga dengan adanya pengukuran ini dapat mengetahui pos - pos operasional yang dapat ditingkatkan efisiensinya serta dapat mengoptimalkan potensi dana terhimpun dan tersalurkan.

\section{KAJIAN PUSTAKA}

\subsection{Konsep Zakat, Infak, dan Sedekah}

Zakat bermakna suci, tumbuh, berkembang dan berkah. Undang - undang No. 23 Tahun 2011 pasal 1 ayat 2 menjelaskan bahwa zakat merupakan harta yang wajib dikeluarkan oleh seorang muslim atau badan usaha untuk diberikan kepada yang berhak menerima sesuai denn syariat islam. Sedangkan dalam fiqh zakat (Kemenag Jatim, 2015:38) zakat merupakan :

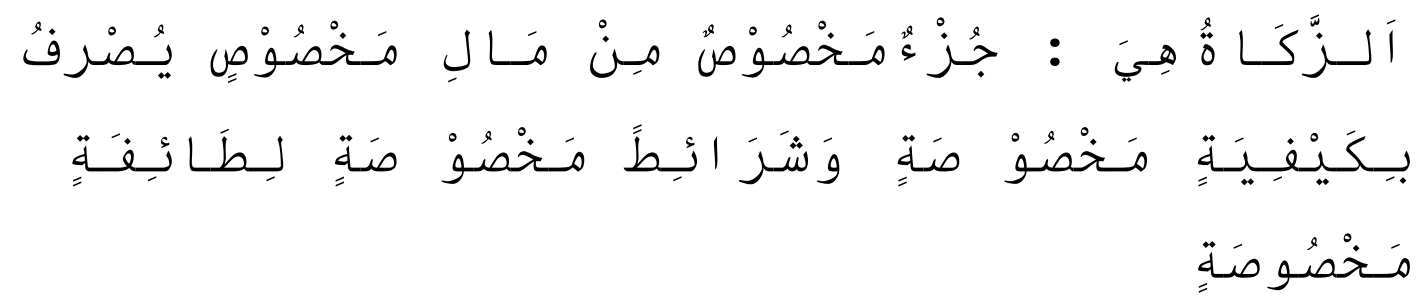

Zakat adalah bagian tertentu dari harta tertentu yang dikeluarkan oleh seorang muslim dengan cara dan syarat - syarat tertentu kepada orang-orang atau badan/lembaga yang tetentu pula. Bagian tertentu dari harta maksudnya yaitu kadar bagian harta yang akan diberikan/didistribusikan sebagai zakat. Bagian ini berkisar pada 2,5\%,5\%,10\%, 20\% atau satu mud (lebih kurang 2,7 kg). Dasar hukum zakat yang telah diatur dalam al- Qur'an dalam Qs. Al Baqarah:43 :

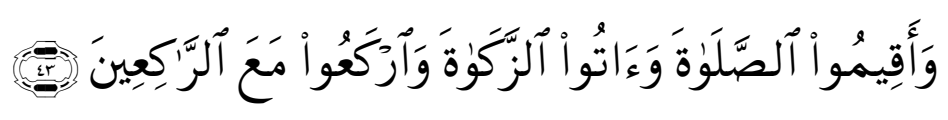


' 'Dan dirikanlah shalat dan tunaikanlah zakat serta rukuklah bersama orang- orang yang rukuk '(Qs. Al- Baqarah : 43)

Ayat tersebut menjelaskan bahwa pentingnya berzakat sebanding dengan pentingnya menunaikan sholat bagi seorang muslim. Selain itu disebutkan dalam Al-qur'an surat Adz - Dzaariat ayat 19 mengenai kewajiban untuk membayar zakat bagi seorang muslim, sebagai berikut:

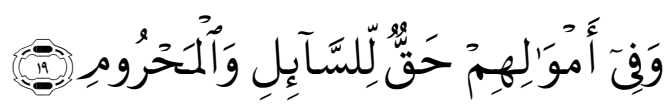

' Dan setiap harta terdapat hak orang lain (orang yang meminta- minta dan orang yang tidak meminta-minta)" (QS.Adz-dzariaat : 19)

Makna dari ayat tersebut yakni setiap harta seorang muslim sebenarnya bukan sepenuhnya miliknya tetapi ada hak atau milik orang lain di dalamnya dan kewajiban bagi setiap muslim untuk mengeluarkan zakat, infak dan sedekah. Apabila seorang muslim tidak mengeluarkannya berarti telah berlaku dzalim khususnya kepada kaum dhuafa.

Undang - undang nomor 23 Tahun 2011 pasal 1 ayat 3 menjelaskan bahwa infak adalah harta yang dikeluarkan oleh seseorang atau badan usaha di luar zakat untuk tujuan kemaslahatan umum. Perintah berinfak terdapat dalam Qs. Al - Baqarah ayat 267 :

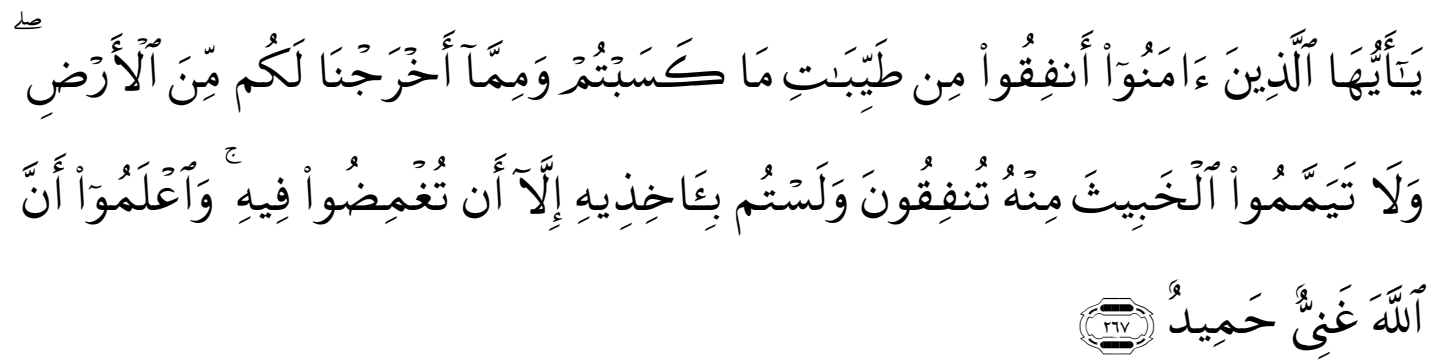

"Hai orang-orang yang beriman, nafkahkanlah (di jalan Allah) sebagian dari hasil usahamu yang baik-baik dan sebagian dari apa yang Kami keluarkan dari bumi untuk kamu. dan janganlah kaтu memilih yang buruk-buruk lalu kamu menafkahkan daripadanya, Padahal kamu sendiri tidak mau mengambilnya melainkan dengan memincingkan mata terhadapnya. dan ketahuilah, bahwa Allah Maha Kaya lagi Maha Terpuji'. (Al- Baqarah : 267)

Undang - undang nomor 23 Tahun 2011 pasal 1 ayat 4 menjelaskan bahwa sedekah adalah harta atau non harta yang dikeluarkan oleh seseorang atau badan usaha di luar zakat untuk tujuan kemaslahatan umum. Hukum sedekah adalah sunah, anjuran bersedekah terdapat dalam Qs. At Taubah ayat 103 : 


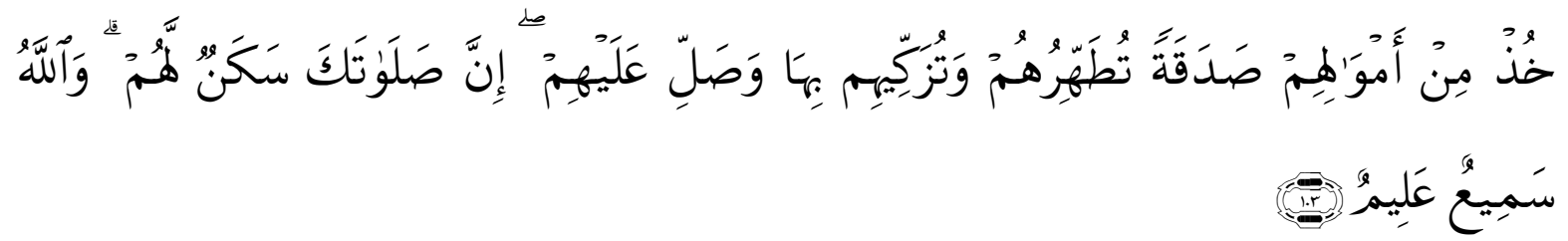

“ ambillah zakat dari sebagian harta mereka, dengan zakat itu kamu membersihkan dan mensucikan mereka dan mendoalah untuk mereka. Sesungguhnya doa kamu itu (menjadi) ketenteraman jiwa bagi mereka. dan Allah Maha mendengar lagi Maha mengetahui”. (Qs. Al-Taubah:103)

Ayat diatas menyebutkan mengenai harta benda dan juga sedekah, maka yang dimaksud dengan sedekah adalah menyangkut baik zakat maupun infak. Zakat adalah sedekah yang diambil dari sebagian harta dari seorang muslim. Sedangkan infak adalah sedekah yang diambil dari penghasilan (Kemenag RI, 2015 : 297).

Secara umum pengoptimalan pengelolaan dan pemanfaatan zakat, infak, dan sedekah dilakukan berdasarkan skala prioritas kebutuhan mustahik serta pendayagunaan dimanfaatkan untuk usaha produktif. Sebagai sebuah industri publik organisasi pengelola zakat dituntut memiliki sifat amanah, profesional, transparan dan akuntabilitas serta kemandirian menuju masyarakat yang sejahtera, berdaya, dan bertaqwa demi mewujudkan optimalisasi pengelolaan zakat di Indonesia yang lebih baik.

\subsection{Pengelolaan}

Upaya untuk meningkatkan pengelolaan dana secara profesional perlu adanya pengelolaan zakat,infak dan sedekah secara melembaga. Sesuai Undang - Undang No. 23 Tahun 2011 pengelolaan zakat, infak dan sedekah merupakan kegiatan perencanaan, pelaksanaan, dan pengordinasian dalam pengumpulan, pendistribusian dan pendayagunaan zakat, infak dan sedekah. Tujuan pengelolaan zakat, infak dan sedekah sesuai dengan Undang - undang No.23 Tahun 2011 yakni meningkatkan efektivitas dan efisiensi pelayanan dalam pengelolaan zakat, infak, sedekah serta meningkatkan manfaat zakat, infak, sedekah untuk mewujudkan kesejahteraan masyarakat dan penanggulangan kemiskinan. Terdapat dua jenis lembaga pengelola zakat, infak dan sedekah di Indonesia lembaga yang dibentuk oleh pemerintah maupun masyarakat. Adapun lembaga yang dibentuk pemerintah ialah Badan Amil Zakat Nasional (BAZNAS) dan Lembaga Amil Zakat (LAZ) yang dibentuk oleh masyarakat.

Badan Amil Zakat Nasional (BAZNAS) merupakan lembaga amil zakat dibentuk oleh pemerintah dari tingkat pusat sampai dengan tingkat daerah yang bertugas untuk melakukan pengelolaan zakat, infak, sedekah secara nasional. BAZNAS merupakan lembaga non struktural yang bertanggungjawab kepada Presiden melalui Menteri. Sumber pendanaan untuk kegiatan operasional BAZNAS bersumber dari anggaran APBN dan hak amil. Dalam melaksanakan tugasnya BAZNAS menyelenggarakan fungsinya sebagai berikut (Kemenag, 2015 :339) : 
1. Perencanaan pengumpulan, pendistribusian, dan pendayagunaan zakat

2. Pelaksanaan Pengumpulan, Pendistribusian, dan pendayagunaan zakat

3. Pengendalian pengumpulan, pendistribusian,dan pendayagunaan zakat

4. Pelaporan dan pertanggungjawaban pelaksanaan pengelolan zakat

Lembaga Amil Zakat (LAZ) merupakan lembaga yang dibentuk masyarakat yang memiliki tugas membantu tugas BAZNAS dalam pengumpulan, pendistribusian, dan pendayagunaan zakat. Pembentukan lembaga amil zakat harus mendapat izin dari menteri atau pejabat yang ditunjuk oleh menteri dan mendapat rekomendasi dari BAZNAS, memiliki pengawas syariah, dalam melaksanakan tugasnya lembaga amil zakat harus memiliki kemampuan teknis, administratif dan keuangan. Sumber pendanaan untuk kegiatan operasional lembaga berasal dari hak amil baik berasal dari dana zakat, infak, dan sedekah (Kemenag, 2015 : 337).

Dalam rangka meningkatkan daya guna dan hasil guna, ZIS harus dikelola secara melembaga sesuai dengan syariat islam, amanah, kemanfaatan, keadilan hukum, terintegrasi, dan akuntabilitas sehingga dapat meningkatkan evektifitas dan efisiensi pelayanan dalam pengelolaan zakat. Kemudian, BAZNAS maupun LAZ wajib melaporkan kegiatan pengelolaan zakat, infak, dan dana sosial keagamaan lainnya kepada menteri secara berkala sebagai bentuk pertanggungjawaban atas dana yang telah dikelola.

\subsection{Laporan Keuangan Organisasi Pengelola Zakat}

Bagi lembaga zakat, sebuah laporan keuangan menjadi media komunikasi antara lembaga amil dengan pihak lainnya. Laporan keuangan merupakan bentuk pertanggungjawaban operasional lembaga atas pengelolaan dana zakat, infak dan sedekah menyangkut pelaporan penghimpunan, penyaluran, serta pendayagunaan dana zakat, infak dan sedekah. Semakin baik dan profesional kinerja lembaga dalam mengelola dana yang telah di berikan kepada mereka, maka akan semakin tinggi kepercayaan para muzaki kepada lembaga tersebut atas dana yang telah diamanahkan kepada lembaga. Laporan keuangan bermanfaat untuk berbagai pihak berkepentingan guna sebagai bahan pengambilan keputusan ekonomi dan sosial (Rahman,2015 : 153).

Laporan keuangan organisasi pengelola zakat mengacu pada PSAK No.109 yang berisi mengenai pedoman pencatatan akuntansi zakat, infak dan sedekah terdiri dari beberapa komponen, terdiri dari: Neraca (laporan posisi keuangan), Laporan perubahan dana, Laporan perubahan aset kelolaan, Laporan arus kas, Catatan atas laporan keuangan ( Nurhayati \& Wasilah, 2004 : 317).

Laporan keuangan lembaga zakat di susun oleh seorang akuntan. Seorang akuntan organisasi pengelola zakat harus mengetahui pengalokasian dana zakat dengan tujuan agar proses pencatatan yang dilakukan sesuai dengan ketentuan syariah khususnya pada alokasi dana untuk amil. Alokasi dana amil harus memperhatikan proporsi penyaluran untuk asnaf maupun untuk amil. Hak amil mencapai $1 / 8$ bagian $(12,5 \%)$ dari asnaf lainnya. Alokasi dana sebesar itu harus disertai dengan kinerja 
penyaluran yang sebanding dengan hak yang diterima amil. Peningkatan kinerja amil dalam menyalurkan dana zakat sesuai dengan ketentuan syariah akan meningkatkan kepercayaan publik terhadap organisasi pengelola zakat (Muslim, 2015:340).

\subsection{Efisiensi}

\subsubsection{Pengertian Efisiensi}

Kinerja organisasi merupakan suatu hasil yang dapat diukur dengan menggambarkan kondisi suatu organisasi. Pengukuran kinerja pada organisasi nirlaba bertujuan untuk mengembangkan program kerja lembaga dimasa mendatang. Penilaian kinerja dilakukan sebagai bahan evaluasi organisasi agar tersebut terus berusaha memperbaiki kinerjanya, apabila organisasi tersebut terus memperbaiki kinerja maka organisasi tersebut akan tumbuh menjadi organisasi yang akan tumbuh menjadi organisasi yang sehat dengan kepercayaan publik yang baik (Bastiar, 2019:46). Untuk memenuhi standarisasi kinerja yang baik salah satu satu indikator penilaian kinerja lembaga yaitu efisiensi (Wulandari, $2014: 5$ ).

Efisiensi merupakan perbandingan antara keluaran (output) dengan masukan (input). Konsep efisiensi berasal dari konsep ekonomi mikro, yakni pada teori produsen dan konsumen. Teori produsen mencoba untuk memaksimalkan keuntungan dengan meminimalkan biaya. Sedangkan teori konsumen berusaha memaksimalkan tingkat kegunaannya (Sagantha, $2017: 18$ ).

Menurut Karim (2011: 119) , dalam kriteria ekonomi suatu sistem produksi dikatakan efisien apabila memenuhi salah satu dari dua kriteria berikut : mampu meminimalkan biaya untuk memproduksi dengan jumlah yang sama, dan mampu memaksimalkan produksi dengan jumlah biaya yang sama.

Suatu perusahaan atau lembaga dikatakan efisien apabi1a perusahaan tersebut mampu menghasilkan output yang lebih besar dengan menggunakan jumlah input yang sama. Atau menghasilkan jumlah output yang sama, tetapi dengan penggunaan input yang lebih sedikit dibandingkan jumlah input yang digunakan perusahaan lain. Dengan demikian, terdapat tiga faktor penyebab efisiensi, yaitu : apabila dengan input yang sama dapat menghasilkan output yang lebih besar. Dengan input yang lebih kecil dapat menghasilkan output yang sama. Serta, dengan input yang lebih besar dapat menghasilkan jumlah output dengan presentase yang lebih (Hidayat, 2014: 65).

Secara umum efisiensi digunakan untuk mengukur kinerja suatu perusahaan atau organisasi. Suatu perusahaan atau organisasi dikatakan efisien apabila mampu meminimalkan biaya untuk menghasilkan output tertentu atau mampu memaksimalkan keuntungan dengan menggunakan kombinasi input yang ada (Parisi,2017: 65).

Efisiensi dalam islam merupakan perwujudan keuntungan yang optimal dihasilkan melalui kerja keras atau usaha yang optimal untuk menghasilkan sesuatu secara optimal dengan tetap menjaga keseimbangan dan etika syariah. Keuntungan yang diperoleh harus sesuai dengan kerja keras dan 
usaha yang dilakukan (Ascarya dan Ali 2010: 113 ). Konsep efisiensi disebutkan dalam Qs. Al - Isra' ayat 27 :

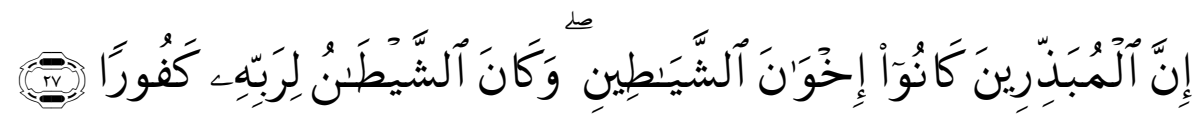

“. Sesungguhnya pemboros-pemboros itu adalah saudara-saudara syaitan dan syaitan itu adalah sangat ingkar kepada Tuhannya." (Qs. Al - Isra' ayat 27).

Ayat tersebut menjelaskan mengenai larangan manusia untuk berperilaku boros. Menekan biaya sekecil mungkin untuk menghasilkan hasil sebanyak - banyaknya hal ini tidak juga tidak diperbolehkan. Namun, tidak dianjurkan juga menggunakan biaya secara berlebihan.

Terdapat tiga jenis efisiensi yaitu (Hidayat, $2014: 67$ ) :

1. Efisiensi teknik menggambarkan kemampuan perusahaan untuk menghasilkan output dengan memanfaatkan input yang ada.

2. Efisiensi alokatif/harga menggambarkan kemampuan perusahaan dalam mengoptimalkan input melalui struktur harga dan teknologi produksinya. Apabila input digunakan untuk menghasilkan output yang tidak terpakai maka input tersebut dikatakan tidak efisien.

3. Efisiensi ekonomi merupakan kemampuan perusahaan dalam meminimalkan biaya produksi untuk menghasilkan output tertentu dengan menggunakan teknologi yang umumnya digunakan dan harga pasar yang berlaku.

\subsubsection{Pengukuran Efisiensi Lembaga Amil Zakat Menggunakan Data Envelopment Analysis}

Data Envelopment Analysis (DEA) merupakan salah satu analisis frontier menggunakan teknik non - parametrik. DEA diciptakan untuk menilai efisiensi relatif dari setiap unit pengambilan keputusan (unit kerja) yang bertanggungjawab menggunakan sejumlah input untuk menghasilkan output yang ditargetkan. Apabila terdapat suatu unit bisnis yang tidak efisien maka analisis frontier akan mengidentifikasi bagaiman sumber daya yang ada dapat dialokasikan lebih efektif dalam rangka meningkatkan efisiensi. Metode data envelopment analysis pada umumnya diperuntukkan untuk menilai efisiensi organisasi pada sektor publik. Terdapat dua model yang sering digunakan dalam pengukuran efisiensi dengan DEA, sebagai berikut (Tanjung dan Devi,2013: 332 - 324):

\section{Constant Return to Scale (CRS)}

Model CRS membandingkan setiap DMU dengan seluruh DMU pada sampel yang digunakan dengan asumsi bahwa kondisi internal dan eksternal DMU adalah sama. Kritik terhadap model ini adalah model ini hanya sesuai dengan kondisi dimana DMU hanya beroperasi pada skala optimal. Efisiensi teknik CRS ini memberikan asumsi jika jumlah input naik sebesar $\mathrm{x}$, maka output juga naik sebesar $\mathrm{x}$. 


\section{Variable Return to Scale (VRS)}

Seringkali persaingan dengan kendala-kendala keuangan dapat menyebabkan suatu unit bisnis tidak beroperasi pada skala optimalnya. Padahal asumsi CRS berlaku jika unit bisnis yang diobservasi beroperasi pada skala optimal. Model VRS berarti bahwa adanya penambahan input sebesar x kali tidak akan menyebabkan output meningkat sebesar x kali, hasil bisa lebih kecil atau lebih besar. Model ini lebih tepat digunakan dalam menganalisis efisiensi pada perusahaan jasa.

Pengukuran efisiensi dengan menggunakan data envelopment analysis dapat dilakukan dengan dua orientasi pengukuran yaitu (Tanjung dan Devi,2013: 322- 324):

1. Pengukuran berorientasi input, menunjukkan sejumlah input dapat dikurangi secara proporsional tanpa mengubah output yang dihasilkan. Pengukuran dengan menggunakan model ini akan menghitung pengurangan input yang diperlukan untuk menghasilkan kinerja yang efisien dengan penggunaan output yang tepat.

2. Pengukuran berorientasi output, mengukur apabila sejumlah output dapat ditingkatkan secara proporsional tanpa mengubah jumlah input yang digunakan. Pengukuran dengan menggunakan model ini akan menghitung peningkatan output yang diperlukan untuk menghasilkan kinerja yang efisien dengan input yang tetap.

Konsep pendekatan, menggambarkan hubungan antara input dan output dalam membentuk sebuah model efisiensi. Untuk itu, dalam pengukuran efisiensi suatu lembaga perlu adanya penentuan variabel input dan output yang akan digunakan. Terdapat tiga pendekatan yang digunakan dalam mengukur efisiensi pada lembaga keuangan maupun lembaga nirlaba khususnya pada lembaga zakat, antara lain (Nurhasanah dan Lubis, 2017 : 109) :

1. Pendekatan Produksi, pendekatan ini mengasumsikan lembaga zakat sebagai produsen dari dana terhimpun dan dana tersalurkan. Sehingga, output dari pendekatan ini yaitu berupa penerimaan maupun pendistribusian dana zakat, infak dan sedekah.

2. Pendekatan Intermediasi, pendekatan ini menganggap lembaga zakat sebagai lembaga intermediator antara muzaki dengan mustahik. Organisasi pengelola zakat berperan sebagai lembaga yang bertugas untuk menyalurkan dana yang diperoleh dari muzaki ke mustahik.

3. Pendekatan Asset, pendekatan ini menganggap lembaga zakat sebagai pendistribusi kredit pinjaman yang outputnya diukur dengan aset - aset yang dimiliki.

\subsubsection{Urgensi Pengukuran Efisiensi pada Organisasi Pengelola Zakat (OPZ)}

Organisasi pengelola zakat merupakan organisasi nirlaba yang sumber dananya berasal dari masyarakat dan harus disalurkan kembali untuk kesejahteraan masyarakat. Organisasi pengelola zakat perlu memperhatikan efisiensi penggunaan dana dalam operasional pengelolaan maupun operasional program. Efisiensi organisasi pengelola zakat yaitu kemampuan lembaga dalam mengelola biaya sekecil mungkin untuk menghasilkan program yang optimal. Untuk memperoleh efisiensi organisasi 
pengelola zakat perlu memperhatikan proporsi biaya yang digunakan (cost) dan manfaat yang akan diperoleh (benefit). Dengan kata lain, dengan memperhatikan proporsi/ menekan biaya yang dikeluarkan akan mampu meningkatkan penyaluran dana untuk penerima manfaat (Kemenag RI, 2012 : 65 - 66). Oleh karena itu, perlu adanya pengukuran kinerja dalam organisasi, pengukuran kinerja ini digunakan sebagai evaluasi akuntabilitas internal maupun eksternal organisasi.

\subsection{Metode Penelitian}

Penelitian ini menggunakan kuantitatif deskriptif, menggunakan data sekunder. Data skunder diperoleh dari laporan keuangan lembaga amil zakat Yayasan Dana Sosial Al - Falah (YDSF) Surabaya periode 2015 - 2017. Populasi dalam penelitian ini yaitu seluruh organisasi pengelola zakat yang beroperasi di Indonesia. Kemudian, penelitian ini menggunakan purposive sampling yaitu lembaga amil zakat nasional Yayasan Dana Sosial Al- Falah (YDSF) Surabaya. Teknik pengumpulan data pada penelitian ini yakni dengan dokumentasi dan wawancara.

Teknik analisis data menggunakan metode non-parametrik Data Envelopment Analysis (DEA). Pengolahan data menggunakan mikrosoft exel dan software data envelopment analysis version 2.1(DEAP 2.1). Objek penelitian yakni laporan keuangan lembaga amil zakat Yayasan Dana Sosial Al-Falah Surabaya periode 2015 - 2017. Menggunakan pendekatan produksi. Variabel input yang digunakan yaitu jumlah aset dan biaya operasional, kemudian variabel output yang digunakan yaitu jumlah dana zakat, infak, dan sedekah terhimpun dan tersalurkan. Selanjutnya pengukuran menggunakan dua orientasi yakni orientasi input dan output.

\section{HASIL DAN PEMBAHASAN}

\subsection{Hasil Analisis Data}

Salah satu parameter untuk mengukur kinerja suatu perusahaan atau organisasi yakni dengan pengukuran efisiensi melalui pengukuran pada aktivitas keuangan lembaga. Organisasi pengelola zakat dikatakan efisien apabila organisasi tersebut mampu mengelola biaya sekecil mungkin untuk menghasilkan program yang optimal.

Sebuah decision making unit (DMU) dikatakan efisien apabila nilai pengukuran menunjukkan $100 \%$ atau 1. Apabila hasil pengukuran kurang dari $100 \%$ atau 1 dan semakin mendekati angka 0 maka DMU tersebut tidak efisien (Hidayat,2014 : 99 ).

Pengukuran menggunakan asumsi variable return to scale (VRS), kemudian menggunakan dua orientasi yakni orientasi input dan output, pengukuran berorientasi input artinya perhitungan efisiensi dengan mengutamakan pada minimalisasi penggunaan input untuk hasil yang efisien, sedangkan pengukuran berorintasi output yang berarti menghitung peningkatan output yang diperlukan untuk untuk menghasilkan kinerja yang efisien dengan input yang tetap. Menggunakan pendekatan produksi, pendekatan ini mengasumsikan lembaga zakat Yayasan Dana Sosial Al - Falah (YDSF) Surabaya 
sebagai pengelola biaya guna menghimpun maupun mendistribusikan dana zakat, infak dan sedekah secara efisien. Variabel input : jumlah aset, biaya operasional. Serta output : dana zakat, infak, dan sedekah terhimpun dan tersalurkan. Sedangkan aplikasi pengolah data yang digunakan yaitu Data Envelopment Analysis Version 2.1(DEAP 2.1). Berikut merupakan hasil pengukuran efisiensi lembaga zakat Yayasan Dana Sosial Al - Falah periode 2015 - 2017 dengan software DEAP 2.1 :

Tabel 1. Hasil pengukuran efisiensi YDSF

\begin{tabular}{ccc}
\hline Tahun & Orientasi Input $(\%)$ & Orientasi Output $(\%)$ \\
\hline 2015 & 100 & 100 \\
2016 & 100 & 100 \\
2017 & 100 & 100 \\
\hline
\end{tabular}

Sumber : output DEAP 2.1,(diolah)

Berdasarkan hasil pengukuran efisiensi selama tiga periode pengukuran (2015 -2017) menunjukkan nilai maksimal yaitu 100 persen baik pada pengukuran berorientasi input maupun output, Hal ini berarti pengukuran telah mencapai target efisiensi, dimana YDSF telah optimal dalam penggunaan input maupun output serta tidak perlu adanya peningkatan pada variabel otput maupun penurunan pada variabel input. Sehingga dalam tiga tahun berturut - turut Yayasan Dana Sosial AlFalah (YDSF) telah mencapai kinerja yang efisien, yang artinya YDSF telah mampu memaksimalkan penggunaan input maupun otput. Selain pengukuran efisiensi secara keseluruhan, selanjutnya perlu adanya analisis pada setiap variabel, tujuannya yaitu untuk mengetahui variabel yang perlu ditekan maupun ditingkatkan penggunaannya. Pada pengukuran terdapat presentase angka target, angka target merupakan nilai yang disarankan atau angka yang dapat dicapai dari pengukuran DEA agar tercapainya nilai efisiensi pada input maupun output. Kemudian terdapat istilah to gain merupakan presentase penambahan angka agar mencapai target yang dihasilkan. Berikut angka aktual dan target pengukuran:

a. Efisiensi Yayasan Dana Sosial Al-Falah periode 2015

Berdasarkan tabel 1 menunjukkan bahwa tahun 2015 telah mencapai kinerja yang efisien dengan nilai pengukuran 100 atau 1, dimana YDSF telah mencapai angka aktual dan target pada setiap variabelnya sesuai pengukuran DEA, sebagai berikut :

Tabel 2. Angka aktual dan target efisiens i tahun 2015

\begin{tabular}{lcccc}
\hline \multicolumn{1}{c}{ Variabel } & Aktual & Target & To gain & Efisiensi \\
\hline $\begin{array}{l}\text { Jumlah aset } \\
\text { Biaya }\end{array}$ & 5.101 .964 .231 & 5.101 .964 .231 & $0.0 \%$ & $100 \%$ \\
operasional & 6.968 .170 .383 & 6.968 .170 .383 & $0.0 \%$ & $100 \%$
\end{tabular}




\begin{tabular}{lllll}
$\begin{array}{l}\text { Dana ZIS } \\
\text { terhimpun }\end{array}$ & 39.889 .624 .540 & 39.889 .624 .540 & $0.0 \%$ & $100 \%$ \\
$\begin{array}{l}\text { Dana ZIS } \\
\text { tersalurkan }\end{array}$ & 35.433 .743 .236 & 35.433 .743 .236 & $0.0 \%$ & $100 \%$ \\
\hline
\end{tabular}

Sumber : output DEAP 2.1,(diolah)

Tabel 2 menunjukkan tahun 2015 YDSF telah mengalami kinerja yang optimal hal ini dibuktikan dari hasil pengukuran nilai efisiensi sebesar 100 persen, yang artinya pengukuran telah mencapai nilai aktual (nilai sebenarnya) dan nilai target (nilai harus dicapai) pada penggunaan input maupun output. Sehingga tidak perlu adanya peningkatan pada variabel output maupun penurunan dari variabel input karena telah sesuai nilai yang disarankan dalam pengukuran DEA. Hal ini menunjukkan bahwa kinerja pengelolaan keuangan YDSF pada tahun 2015 tersebut telah efisien sebagai lembaga yang berfungsi menghimpun maupun menyalurkan dana zakat, infak dan sedekah dengan sangat baik dimana pada pengukuran telah mencapai proporsi atau meminimalkan biaya guna menghasilkan output yang maksimal.

b. Efisiensi Yayasan Dana Sosial Al-Falah periode 2016

Berdasarkan tabel 1 menunjukkan bahwa tahun 2015 Yayasan Dana Sosial Al- Falah telah mencapai kinerja yang efisien, dengan nilai pengukuran 100 atau 1, yang artinya YDSF telah mampu memaksimalkan penggunaan input maupun otput, dimana YDSF telah mencapai angka aktual dan target pada setiap variabelnya sesuai pengukuran DEA, sebagai berikut :

Tabel 3. Angka aktual dan target efisiensi tahun 2016

\begin{tabular}{lllll}
\hline Variabel & Aktual & Target & To gain & Efisiensi \\
\hline $\begin{array}{l}\text { Jumlah aset } \\
\text { Biaya }\end{array}$ & 7.220 .103 .294 & 7.220 .103 .294 & $0.0 \%$ & $100 \%$ \\
$\begin{array}{l}\text { operasional } \\
\text { Dana ZIS }\end{array}$ & 6.913 .866 .343 & 6.913 .866 .343 & $0.0 \%$ & $100 \%$ \\
$\begin{array}{l}\text { terhimpun } \\
\text { Dana ZIS }\end{array}$ & 41.619 .799 .069 & 41.619 .799 .069 & $0.0 \%$ & $100 \%$ \\
tersalurkan & 32.837 .820 .463 & 32.837 .820 .463 & $0.0 \%$ & $100 \%$ \\
\hline
\end{tabular}

Sumber : output DEAP 2.1,(diolah)

Tabel 3 menunjukkan pada tahun 2016 YDSF kembali mengalami kinerja yang efisien hal ini dibuktikan dari hasil pengukuran nilai efisiensi sebesar 100 persen, yang artinya pengukuran telah mencapai nilai aktual (nilai sebenarnya) dan nilai target (nilai harus dicapai) pada penggunaan input maupun output. Sehingga tidak perlu adanya peningkatan pada variabel output maupun penurunan dari variabel input karena telah sesuai nilai yang disarankan dalam pengukuran DEA. Hal tersebut 
menunjukkan bahwa kinerja YDSF pada tahun 2015 tersebut sudah baik dimana dalam penggunaan biaya guna menghasilkan output yang maksimal.

c. Efisiensi Yayasan Dana Sosial Al-Falah periode 2017

Tabel 4. Angka aktual dan target efisiensi tahun 2017

\begin{tabular}{lcccc}
\hline \multicolumn{1}{c}{ Variabel } & Aktual & Target & To gain & Efisiensi \\
\hline Jumlah aset & 8.545 .130 .571 & 8.545 .130 .571 & $0.0 \%$ & $100 \%$ \\
$\begin{array}{l}\text { Biaya } \\
\text { operasional }\end{array}$ & 7.294 .633 .238 & 7.294 .633 .238 & $0.0 \%$ & $100 \%$ \\
$\begin{array}{l}\text { Dana ZIS } \\
\text { terhimpun }\end{array}$ & 43.392 .772 .560 & 43.392 .772 .560 & $0.0 \%$ & $100 \%$ \\
$\begin{array}{l}\text { Dana ZIS } \\
\text { tersalurkan }\end{array}$ & 42.232 .059 .184 & 42.232 .059 .184 & $0.0 \%$ & $100 \%$ \\
\hline
\end{tabular}

Sumber : output DEAP 2.1,(diolah)

Kemudian, nilai efisiensi YDSF tahun 2017 kembali menunjukkan angka 100 persen, hal ini berarti YDSF selalu konsisten untuk mempertahankan efisiensi kinerja lembaga dari tahun ke tahun. Dimana dalam pengukuran YDSF telah mencapai nilai aktual (nilai sebenarnya) dan nilai target (nilai harus dicapai) pada penggunaan input maupun output. Dapat dikatakan kinerja YDSF sudah sangat baik dalam pengelolaan dana zakat, infak dan sedekah. Hal ini terbukti dari penggunaan biaya operasional seminimal mungkin untuk menghasilkan peningkatan penghimpunan maupun penyaluran dana zakat, infak dan sedekah pada setiap tahunnya, terutama pada tahun 2017 ini dimana terjadinya kenaikan penghimpunan serta kenaikan yang signifikan pada penyaluran dana zakat, infak, dan sedekah.

\subsection{Pembahasan}

Sebagai lembaga yang berfungsi penghimpun dana zakat, infak, dan sedekah, berdasarkan hasil penelitian menunjukkan bahwa selama tiga periode pengukuran Yayasan Dana Sosial Al - Falah (YDSF) mengalami tingkat efisiensi yang konsisten pada setiap tahunnya, YDSF mengalami efisiensi tahun 2015, 2016, dan 2017. Hal ini dapat dilihat dari hasil pengukuran nilai efisiensi sebesar 100 persen atau 1 pada setiap variabelnya, yang artinya YDSF telah mencapai kinerja yang optimal pada penggunaan input maupun outputnya sesuai pengukuran efisiensi pada DEA.

Penelitian ini sejalan dengan teori Karim (2011: 119) yang menyatakan bahwa dalam ekonomi suatu produksi dikatakan efisien apabila memenuhi salah satu dari dua kriteria berikut : mampu meminimalkan biaya untuk memproduksi dengan jumlah yang sama, dan mampu memaksimalkan produksi dengan jumlah biaya yang sama. Kemudian, penelitian ini juga sejalan dengan teori efisiensi Hidayat (2014 : 65) yang menyatakan lembaga dikatakan efisien apabila mampu menghasilkan output 
yang lebih besar atau sama, dengan menggunakan input yang lebih kecil atau sama. Dalam hal ini YDSF berfungsi sebagai lembaga penghimpun dana telah mampu mengelola modal atau input secara proporsional berupa jumlah aset yang dimiliki dan biaya operasional untuk menghasilkan output berupa dana zakat, infak, dan sedekah terhimpun yang jumlahnya lebih besar dari penggunaan input. $\mathrm{Al}$ - Qur'an menyebutkan bahwasanya manusia hendaknya menggunakan sumber daya (modal) secara efisien, sesuai dengan porsi dan tidak berlebih-lebihan, seperti yang tertuang dalam Qs. Furqon ayat 67 yang berbunyi :

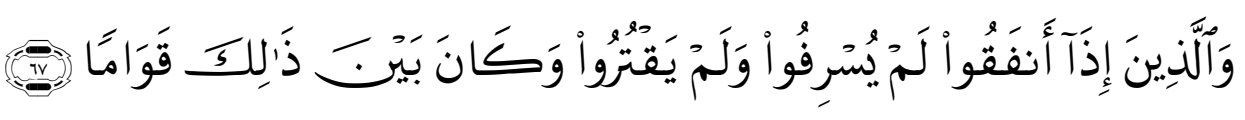

“ dan orang-orang yang apabila membelanjakan (harta), mereka tidak berlebihan, dan tidak (pula) kikir, dan adalah (pembelanjaan itu) di tengah-tengah antara yang demikian.” (Qs. Furqon : 67)

Potongan ayat diatas menjelaskan bahwasanya Allah menganjurkan umatnya untuk tidak membelanjakan harta mereka secara berlebih - lebihan, karena sesuatu yang berlebihan merupakan hal yang tidak baik, begitupula pada lembaga zakat yang dituntun untuk menggunakan input seefisien mungkin terutama pada pengeluaran operasional lembaga dengan tepat guna dan benar, tidak berlebihan serta dalam batas wajar, mengingat lembaga ini merupakan lembaga sosial yang memiliki amanah untuk mengelola dana umat.

Kemudian, fungsi yang kedua yaitu lembaga amil zakat sebagai lembaga yang bertugas menyalurkan dana zakat, infak dan sedekah berdasarkan hasil penelitian menunjukkan bahwa selama tiga periode pengukuran Yayasan Dana Sosial AL - Falah (YDSF) juga mengalami efisiensi yang konsisten setiap tahunnya. Hal ini dibuktikan dari hasil pengukuran yang menunjukkan angka 100 persen pada setiap variabelnya, hal ini berarti YDSF telah mampu mengelola input secara proporsional berupa jumlah jumlah aset dan biaya operasional untuk menghasilkan output atau keluaran berupa dana zakat, infak, dan sedekah yang berhasil disalurkan ke mustahik.

Sebagai lembaga yang berfungsi penghubung antara muzaki dan mustahik hal ini merupakan salah satu bentuk dari tolong menolong terhadap sesama manusia. Penyaluran dana zakat, infak, dan sedekah yang dilakukan lembaga dapat dimanfaatkan mustahik untuk kebutuhan konsumsi guna memenuhi kebutuhan hidupnya maupun berupa usaha- usaha produktif sehingga memiliki keberlangsungan yang nantinya akan berdampak pada kesejahteraan mustahik. Islam telah memerintahkan umat manusia untuk saling bekerjasama dan saling tolong menolong kecuali dalam hal melakukan perbuatan dosa dan aniaya, dijelaskan dalam Qs. Al -Maidah ayat 2, berikut ini: 


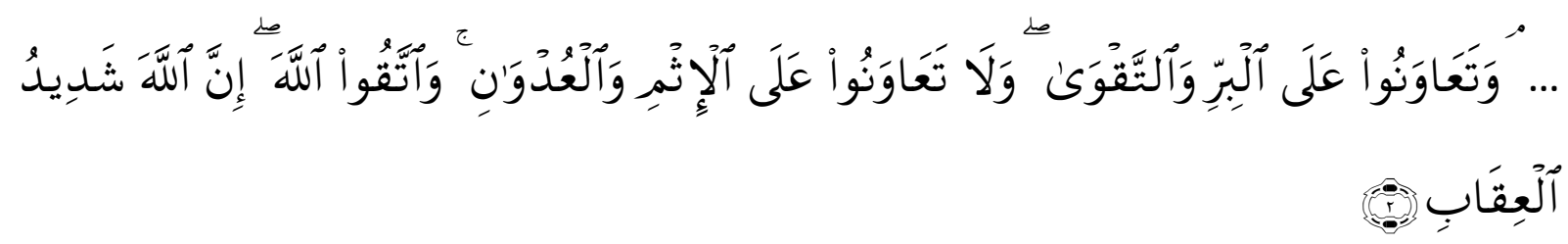

'...Dan tolong - menolonglah kamu dalam (mengerjakan) kebajikan dan takwa, dan jangan tolong - menolong dalam berbuat dosa dan permusuhan. Bertakwalah kepada Allah, sungguh, Allah sangat berat siksa-Nya"'(Qs. Al- Maidah : 2)

Berdasarkan ayat tersebut, Allah memerintahkan umatnya untuk saling tolong menolong dalam hal kebaikan dan melarang tolong - menolong dalam hal keburukan serta penerapan ayat tersebut sesuai dengan fungsi lembaga zakat sebagai penyalur dana ZIS. Penerapan dari ayat tersebut yaitu pada penyaluran dana zakat, infak dan sedekah yang diberikan oleh lembaga zakat kepada mustahik sebagai upaya mengurangi kesenjangan ekonomi dan membantu mensejahterakan masyarakat. Ketiga periode tersebut menunjukkan bahwa lembaga telah efisien dengan tidak berlebihan pada penggunaan dana operasional lembaga, telah sesuainya proporsi jumlah penerimaan dengan peyaluran yang dilakukan, hal ini berarti semakin efisien lembaga mengelola keuangan, maka akan semakin banyak mustahik yang dapat menerima manfaat sehingga menjadikan lembaga tersebut semakin amanah dan tentunya akan mendapatkan kepercayaan lebih dari masyarakat atas profesionalitas pengelolaan dana umat.

Hasil penelitian ini sejalan dengan penelitian yang dilakukan Nurhasanah \& Lubis (2017) dimana pada penggunaan pendekatan produksi dengan input dan output yang sama, pada asumsi variable return to scale (VRS) dengan objek BAZNAS kabupaten Bogor dan Sukabumi, dimana pada penggunaan metode tersebut pengukuran menunjukkan terjadinya efisiensi pada kedua objek penelitian, pada asumsi VRS skor efisiensi terjadi pada kedua periode pengukuran yakni di tahun 2015 dan 2016.

Namun, hasil penelitian ini beranding terbalik dengan penelitian Wulandari (2014) pada beberapa lembaga amil zakat BAZNAS, Bamuis BNI, Rumah Zakat, PKPU, dengan penggunaan pendekatan produksi, penggunaan variabel input dan output sama, periode pengukuran yaitu tahun 2011-2012. Dengan penggunaan variabel yang sama, justru mengalami inefisiensi pada tahun 2012 yakni BAZNAS,Rumah Zakat, dan PKPU. Kemudian di tahun 2013 hasil pengukuran juga mengalami inefisiensi pada Rumah Zakat dan PKPU. Inefisiensi disebabkan oleh variabel input total aset dan biaya operasional yang penggunaanya masih berlebihan pada pos sosialisasi zizwaf dan gaji amil, serta pada pengalokasian aset yang belum tepat. 


\section{KESIMPULAN}

Berdasarkan hasil analisis, efisiensi pada lembaga zakat Yayasan Dana Sosial Al-Falah (YDSF) Surabaya dengan menggunakan metode DEA pada periode 2015 - 2017, menggunakan pendekatan produksi. Dapat disimpulkan dari hasil penelitian, fungsi lembaga zakat sebagai penghimpun maupun pendistribusi dana zakat, infak, dan sedekah menunjukkan efisiensi pada ketiga periode penelitian yakni tahun 2015, 2016, dan 2017, dengan nilai efisiensi maksimal 100 persen. Hal tersebut menunjukkan YDSF telah mencapai kinerja yang optimal pada penggunaan input berupa biaya operasional yang digunakan telah tepat guna, sehingga tidak mengalami pemborosan serta pada penggunaan aset telah dialokasikan pada hal - hal produktif terutama pada penggunaan aset yang telah maksimal. Maupun pada hasil pengukuran output yakni pada penerimaan dan penyaluran yang telah sesuai dengan nilai aktual dan target pada pengukuran DEA. Benchmark pada ketiga periode pengukuran tersebut yakni pada tahun 2017.

Sebagai lembaga sosial yang memiliki dua fungsi Yayasan Dana Sosial Al- Falah (YDSF) Surabaya telah bekerja sangat baik, dimana berdasarkan analisis selama tiga tahun berturut- turut Yayasan Dana Sosial Al- Falah selalu konsisten dengan nilai efisiensinya, sesuai dengan citra lembaga sebagai pioner lembaga zakat di Indonesia yang telah berdiri selama 32 tahun tentunya telah profesional dan amanah dalam mengelola dana zakat, infak dan sedekah sesuai dengan misi lembaga. Yayasan Dana Sosial Al- Falah perlu mempertahankan kinerja lembaga yang efisien, guna untuk mempertahankan kepercayaan masyarakat terhadap lembaga serta guna untuk mewujudkan kesejahteraan masyarakat, diharapkan melalui kinerja lembaga yang efisien mampu memberikan manfaat lebih banyak lagi kepada mustahik dari penyaluran dana zakat, infak, dan sedekah. 


\section{DAFTAR PUSTAKA}

Akbar, N. (2009). Analisis Efisiensi Organisasi Pengelola Zakat Nasional dengan Pendekatan Data Envelopment Analysis. Tazkia Islamic Finance and Business Review, 4(2), 760-784.

Ali, M. \& A. (2010). Analisis Efisiensi Baitul Maal Wat Tamwil Dengan Pendekatan Two Stage Data Envelopment Analysis (Studi Kasus Kantor Cabang BMT MMU Dan BMT UGT Sidogiri). TAZKIA Islamic Finance \& Business Review M. Mahbubi Ali Ascarya TAZKIA Islamic Finance \& Business Review, 5(52), 110-125.

Badan Amil Zakat Nasional. (2019). Otlook Zakat Indonesia 2019 (BAZNAS, Ed.). Retrieved from www.puskasbaznas.com

Bastiar, Y., \& Bahri, E. S. (2019). Model Pengkuran Kinerja Lembaga Zakat di Indonesia. ZISWAF : Jurnal Zakat Dan Wakaf, 6(1), 43. https://doi.org/10.21043/ziswaf.v1i1.5609

Canggih, C., Fikriyah, K., \& Yasin, A. (2017). Potensi Dan Realisasi Dana Zakat Indonesia. Al-Uqud: Journal of Islamic Economics, 1(1), 14. https://doi.org/10.26740/jie.v1n1.p14-26

Departemen Agama. (2009). Al - Quran dan Terjemahan. Retrieved from www.sygmacorps.com

Hidayat, M. (2010). An Introduction To The Sharia Economic. Jakarta: Zikru Hakim.

Hidayat, R. (2014). Efisiensi Perbankan Syariah : Teori dan Praktik. Jakarta : Gratama Publishing.

Karim, A. (2011). Ekonomi Mikro Islam. Jakarta: Rajawali Pers.

Kementerian Agama Jawa Timur. (2015). Fiqh Zakat. Jawa Timur: Kementerian Agama Jawa Timur.

Kementerian Agama RI. (2012). Manajemen Pengelolaan Zakat. Jakarta: Kementerian Agama Republik Indonesia.

Kementerian Agama RI. (2015). Pedoman Zakat Sembilan Seri. Jakarta: Kementerian Agama Republik Indonesia.

Mawaryani, A. (2016). Analisis Efisiensi Lembaga Amil Zakat (LAZ) Di Indonesia Menggunakan Data Envelopment Analysis (DEA) Periode 2012 - 2013. Universitas Muhamadiyah Surakarta.

Mukhlis, A., \& Beik, I. . (2013). Analisis Faktor-faktor yang Memengaruhi Tingkat Kepatuhan Membayar Zakat: Studi Kasus Kabupaten Bogor. Al-Muzara'ah, 1(1), 83-106. https://doi.org/10.29244/jam.1.1.83-106

Muslim, S. (2015). Akuntansi Keuangan Syariah Teori \& Praktik. Bandung: Pustaka Setia.

Nurhasanah, S., \& Lubis, D. (2019). Efisiensi Kinerja BAZNAS Bogor Dan Sukabumi: Pendekatan Data Envelopment Analysis. Jurnal Akuntansi Dan Keuangan Islam, 5(2), 105-120. https://doi.org/10.35836/jakis.v5i2.17

Nurhayati, S. \& Wasilah. (2017). Akuntansi Syariah di Indonesia. Jakarta: Salemba Empat.

Parisi, S. A. (2017). Tingkat Efisiensi dan Produktivitas Lembaga Zakat di Indonesia. Esensi, 7(1). https://doi.org/10.15408/ess.v7i1.3687

Rahman, T. (2015). AKUNTANSI ZAKAT, INFAK DAN SEDEKAH (PSAK 109): Upaya Peningkatan Transparansi dan Akuntabilitas Organisasi Pengelola Zakat (OPZ). Muqtasid: Jurnal Ekonomi Dan Perbankan Syariah, 6(1), 141. https://doi.org/10.18326/muqtasid.v6i1.141164 
Sagantha, F. (2017). Analisis Efisiensi Perbankan Syariah Dengan Metode Data Envelopment Analysis (DEA) Dan Nilai Islam Studi Pada Bank Syariah W, X, Y, Z Periode 2010 - 2016. Universitas Islam Negeri Syarif Hidayatulla Jakarta.

Tanjung, H. \& Devi. A. (2013). Metode Penelitian Ekonomi Islam. Jakarta: Gratama Publishing.

Wahyuny, I. . (2016). Efisiensi Organisasi Pengelola Zakat Nasional dengan Metode Data Envelopment Analysis. Journal of Islamic Economics Lariba, 2(1), 1-12. https://doi.org/10.20885/jielariba.vol2.iss1.art1

Wulandari, R. (2014). Analisis Efisiensi Lembaga Zakat Nasional Di Indonesia Menggunakan Data Envelopment Analysis (DEA) Periode 2011 - 2012. Universitas Muhamadiyah Surakarta. 